\title{
Informacje/Information
}

\section{Sprawozdanie \\ z seminarium naukowego „Direct Democracy in Switzerland and beyond", które odbyło się w dniu 5 grudnia 2013 r. na Wydziale Nauk Politycznych i Dziennikarstwa UAM}

Ponad 50 studentów wzięło udział w seminarium naukowym poświęconym demokracji bezpośredniej w Szwajcarii, zorganizowanym w czwartek 5 grudnia przez Grupę Badawczą „Inicjatywa Helwecka" (helwecja.amu.edu.pl), która skupia w swoich szeregach badaczy zorientowanych m.in. wokół szeroko rozumianej tematyki szwajcarskiego systemu politycznego.

Seminarium zorganizowane zostało pod honorowym patronatem Ambasady Szwajcarii w Warszawie, a jego gościem honorowym był Minister Martin Michelet.

Seminarium uroczyście otworzył prodziekan ds. współpracy z zagranicą - dr Tomasz Brańka, po czym rozpoczęła się część zasadnicza seminarium, którą moderował dr Tomasz R. Szymczyński. Jako pierwszy głos zabrał gość honorowy - Minister Martin Michelet, który wygłosił referat pt. Direct Democracy in Switzerland, zwracając uwagę w swoim wystapieniu na głębokie zakorzenienie instytucji demokracji bezpośredniej i zasady federalizmu w historii szwajcarskiego ustroju. Pan Minister podjął również próbę obalenia popularnego mitu, wedle którego referendum jest instytucją wykorzystywaną głównie w związku z jego rzekomą wysoką podatnością na emocje tkwiące w społeczeństwie. M. Michelet podał w tym kontekście przykład jednego z referendów z 2012 roku, w którym większość Szwajcarów opowiedziała się przeciwko postulatowi wydłużenia urlopu do sześciu tygodni. Pan Minister zakończył swoje przemówienie uwagą na temat Landsgemeinde wskazując na fakt, że ta wyjątkowa na skalę światową instytucja do niedawna, w niektórych kantonach, stanowiła podstawową formę sprawowania władzy przez obywateli.

Następnie wystąpiła dr Ewa Myślak z Uniwersytetu Jagiellońskiego, przedstawiając zagadnienie inicjatywy ludowej w Szwajcarii w kontekście wykorzystania tego narzędzia przez ugrupowania polityczne. Doktor Myślak wskazała, że o ile często inicjatorami odpowiedzialnymi za złożenie wniosku o referendum są organizacje samoNGOsy, to zdarza się, że faktycznie organizacje te są w dużym stopniu zależne od partii politycznych. W gruncie rzeczy sprowadza się to do wykorzystywania instytucji demokracji bezpośredniej przez partie polityczne jako kolejnego narzędzia realizowania swoich celów politycznych, w tym m.in. integracji swojego elektoratu.

Następnie głos zabrała dr Magdalena Musiał-Karg (WNPiD UAM), która zaprezentowała fragmenty filmu z pobytu na tegorocznym zgromadzeniu ludowym w kantonie Appenzell Innerhoden, a następnie nakreśliła najważniejsze jej zdaniem zalety i wady zgromadzenia ludowego jako instytucji demokracji bezpośredniej charakterystycznej dla dwóch szwajcarskich kantonów - wymienionego Appenzell oraz Glarus. Pani doktor zauważyła, że Landsgemeinde można traktować jako „najczystszą” formę demokracji bezpośredniej, gdzie suweren, bez żadnych organów pośredniczących, ma możliwość wypowiadania się w ważnych dla tego kantonu kwestiach. Dr Musiał-Karg wskazała również wiele wad, z którymi trudno polemizować, jak np. faktyczne wykluczenie osób niepełnosprawnych z grona osób uczestniczących w Landsgemeinde.

Kolejnym prelegentem był mgr Marcin Łukaszewski (WNPiD UAM), który opierając się na doświadczeniach andorskich i sanmaryńskich, przedstawił swoje refleksje na temat przyszłości instytucji zgromadzenia ludowego w Szwajcarii wobec zmian demograficznych w Europie. O ile w przypadku Andory zgromadzenie ludowe w klasycznej formie nie istniało, to w San Marino in- 
stytucja Arengo była odpowiednikiem szwajcarskiego Landsgemeinde. Zdaniem M. Łukaszewskiego wzrost populacji w każdym z państw, które prowadzi zwykle do przyznania praw politycznych większej liczbie osób, prowadzi do dysfunkcjonalności takiego zgromadzenia, a w efekcie do rezygnacji z instytucji zgromadzenia ludowego na rzecz organu przedstawicielskiego.

Spojrzenie na instytucje demokracji bezpośredniej z perspektywy pozaszwajcarskiej kontynuował w swoim wystapieniu dr Krzysztof Koźbiał (UJ), który wyraźnie podkreślił, że dość często niezauważany przez badaczy Liechtenstein jest drugim, pod względem liczby referendów, państwem europejskim. Dr Koźbiał zwrócił uwagę, że duże znaczenie ma w tym kontekście kultura polityczna obywateli Księstwa, która zbieżna jest z tą, jaka panuje w Szwajcarii. Prelegent wskazał na funkcjonujące w Liechtensteinie trzy formy demokracji bezpośredniej: referendum, inicjatywę ludową oraz, wyjątkową na skalę światową, możliwość odwołania monarchy.

Po wystapieniu dra K. Koźbiała głos zabrał dr T. R. Szymczyński, który zaprosił uczestników seminarium do dyskusji. Najwięcej pytań zostało skierowanych do gościa honorowego, który był pytany m.in. o późne przyznanie praw politycznych kobietom, na które przez wiele lat nie chcieli zgodzić się uczestniczący w referendach mężczyźni, a następnie mężczyźni głosujący na zgromadzeniach ludowych w kantonach Appenzell Innerhoden czy Appenzell Ausserhoden. Wśród pytań pojawiła się również kwestia języków w Szwajcarii i pytanie o oficjalną nazwę państwa. Pan Minister thumaczył, że federacja szwajcarska nosi miano Konfederacji Szwajcarskiej m.in. ze względu na tradycyjne przywiązanie do nazwy, które niejako nie pozwoliło żadnemu z poważnych polityków na publiczne rozważenie możliwości dostosowania nazwy państwa do federalnego ustroju, który istnieje już od połowy XIX wieku.

Spotkanie zakończyło się krótkim podsumowaniem oraz deklarację dalszych spotkań naukowych mających na celu pogłębianie wiedzy na temat Konfederacji Szwajcarskiej.

W seminarium, poza Ministrem Martinem Michelet, uczestniczyli członkowie Grupy Badawczej „Inicjatywa Helwecka” (dr Krzysztof Koźbiał, dr Ewa Myślak, dr Agnieszka Nitszke (UJ), dr Magdalena Musiał-Karg (WNPiD UAM), dr Marcin Rachwał (WNPiD UAM), dr Tomasz R. Szymczyński (WNPiD UAM), mgr Marcin Łukaszewski (WNPiD UAM). Film prezentowany podczas seminarium nagrał i zmontował mgr Krzysztof Duda (WNPiD UAM).

Po zakończeniu oficjalnej części seminarium, miało miejsce spotkanie przedstawicieli Grupy Badawczej z Ministrem M. Micheletem, które dotyczyło dalszej współpracy z Ambasadą Szwajcarii.

Grupa Badawcza „, Inicjatywa Helwecka” powołana została na Wydziale Nauk Politycznych i Dziennikarstwa UAM w marcu 2013 r. Celem dziatań ,Inicjatywy Helweckiej” jest prowadzenie interdyscyplinarnych badań nad Konfederacja Szwajcarska (m.in. szwajcarskim systemem politycznym, federalizmem, demokracja bezpośrednia, stosunkami Szwajcarii np. z Polska i innymi państwami, relacjami na linii Szwajcaria-UE), wymiana wiedzy i doświadczeń zwiazanych z badaniami ww. zagadnień, organizowanie przedsięwzięć naukowych poświęconych Szwajcarii, a także realizacja różnego rodzaju projektów, grantów o charakterze krajowym i międzynarodowym, których tematyka zwiqzana byłaby z szeroko rozumiana politykq szwajcarska. Mimo krótkiego okresu swojej działalności, „,Inicjatywa Helwecka” zjednoczyła już 15 osób z różnych ośrodków naukowych z całej Polski. Więcej informacji na temat Grupy dostęnych jest na stronie internetowej www.helwecja.amu.edu.pl.

Marcin ŁUKASZEWSKI 


\section{Informacja \\ o laureatach Konkursu im. Profesora Czesława Mojsiewicza na najlepszą książkę o tematyce politologicznej}

Kapituła drugiej edycji Ogólnopolskiego Konkursu im. Profesora Czesława Mojsiewicza na najlepszą książkę o tematyce politologicznej, w dniu 21 listopada 2013 r. dokonała oceny merytorycznej zgłoszonych publikacji, jakie ukazały się w 2012 r. Biorąc pod uwagę cele Konkursu, którymi są:

a) popularyzacja wiedzy o polityce $i$ naukach zainteresowanych ta sfera życia spotecznego;

b) zainteresowanie, szczególnie młodych naukowców, badaniem życia politycznego $w$ wymiarze krajowym, regionalnym lub globalnym;

c) nagradzanie badaczy wyróżniajacych się rzetelnościq, innowacyjnościq oraz troskq o wysoka efektywność i jakość prowadzonych badań;

d) zachowanie pamięci o Profesorze Czesławie Mojsiewiczu i jego dorobku naukowym,

Kapituła postanowiła przyznać nagrodę publikacji Krzysztofa Kowalczyka, Partie i ugrupowania parlamentarne wobec Kościola katolickiego w Polsce w latach 1989-2011, wydanej przez Wydawnictwo Zapol.

Ponadto, Kapituła Konkursu postanowiła wyróżnić prace: Marcina Czyżniewskiego Idee w polityce Vaclava Klausa, wydanej przez Wydawnictwo Naukowe Uniwersytetu Mikołaja Kopernika; Tomasza Grzegorza Grosse, W objęciach Europeizacji. Wybrane przykłady z Europy Środkowej $i$ Wschodniej, wydanej przez Instytut Studiów Politycznych Polskiej Akademii Nauk; Michała Pierzgalskiego, Metody ilościowe w badaniu systemów wyborczych. Na przykładach z państw Azji Wschodniej, wydanej przez Wydawnictwo Uniwersytetu Łódzkiego. Specjalnym wyróżnieniem postanowiono uhonorować także czasopismo „Polish Political Science Yearbook”, ogłaszane drukiem przez Wydawnictwo Adam Marszałek w Toruniu, za rolę jaką odgrywa w krzewieniu dorobku polskiej politologii.

Nagroda i wyróżnienia wręczone zostaną podczas inauguracji corocznej międzynarodowej konferencji z cyklu „Europa XXI wieku” organizowanej przez Wydział Nauk Politycznych i Dziennikarstwa UAM w Collegium Polonicum w Słubicach. Tematem przewodnim XIV już konferencji będzie „10 lat po rozszerzeniu Unii Europejskiej z roku 2004. Diagnozy i scenariusze na przyszłość. Odbędzie się ona 6-7 lutego 2014 r.

Przewodniczący Kapituły

prof. UAM dr hab. Tadeusz WALLAS 
